\title{
Osmanlı Dönemi Mesleki Müzik Eğitiminde İki Solfej Kitabı: Solfej ve Talim-i Kırâat-ı Musiki"
}

\section{Two Solfege Books in Professional Music Education in The Ottoman Period: Solfej and Talim-i Kirâat-i Musiki}

\author{
Gökhan YALÇIN ${ }^{1} \oplus$, Abdulkadir İDE ${ }^{2}$ (])
}

*Bu çalışma MÜZED Uluslararası 2. Ipek Yolu Müzik Konferansı'nda bildiri olarak sunulmuştur.

'Sorumlu yazar/Corresponding author: Gökhan Yalçın (Doç. Dr.),

Harran Üniversitesi, Eğitim Fakültesi, Güzel

Sanatlar Eğitimi Bölümü, Müzik Eğitimi Anabilim

Dalı, Sanlıurfa, Türkiye

E-posta: gyalcin@hotmail.com

ORCID: 0000-0003-2604-9745

${ }^{2}$ Abdulkadir İde (Yüksek Lisans Öğrencisi), Kırıkkale Üniversitesi, Sosyal Bilimler Enstitüsü, Müzik Bölümü, Kırıkkale, Türkiye E-posta: a.kadiride@hotmail.com ORCID: 0000-0003-3869-2738

Başvuru/Submitted: 09.05.2019 Revizyon Talebi/Revision Requested: 19.07.2019

Son Revizyon/Last Revision Received: 12.10.2019

Kabul/Accepted: 15.10.2019

Online Yayın/Published Online: 26.11.2019

Atıf/Citation: Yalcin, Gokhan ve Ide, Abdulkadir. "Osmanlı Dönemi Mesleki Müzik Eğitiminde Iki Solfej Kitabı: Solfej ve Talim-i Kırâat-ı Musiki." Türkiyat Mecmuası-Journal of Turkology 29, 2 (2019): 645-662.

https://doi.org/10.26650/iuturkiyat.651192 öz

Osmanlı dönemi'nde Batı müziği II. Mahmud zamanında (1826) mehter takımının kaldırılarak askeri bandonun kurulması ile kabul edilmeye ve Muzıka-i Hümâyun'un kurulması, İtalyan besteci Giuseppe Donizetti'nin getirilmesi ile birlikte Türk müziğinin yanı sıra Batı müzik eğitimi de resmen verilmeye başlamıştır. Donizetti Paşa 1856'da, Callisto Guatelli 1899'da vefatına kadar ve ardından da D'Arenda Paşa Muzıka-yı Hümâyun'da birçok öğrenci yetiştirmişlerdir. Muzıka-i Hümâyun'da yetişen Türk öğrenciler, Batı müziği nazariyatı ve solfej eğitimine yönelik çeviri ya da telif birçok kitap yayınlamışlardır. Bu yayınlar arasında ilk ve en önemli eserlerden ikisi flütist Mustafa Safvet [Atabinen] Bey'e ait Solfej Yahud Nazariyat-ı Musiki (1888/1889) ve Mehmed Zati [Arca] Bey'e ait Kütübhane-i Musikiden Talim-i Kıraat-ı Musiki (1899/1900) adlı eserlerdir. Bu eserler Osmanlı dönemi'nin ilk basılı Türkçe solfej kitaplarıdır. Çalışmanın amacı da eserlerin eski harflerden yeni harflere çevirmek sureti ile kullanılan terimlerin günümüze yansımalarını incelemek, kitaplarda yer verilen solfej örneklerinin günümüz mesleki müzik eğitiminde kullanılabilirliğini araştırmak olarak belirlenmiştir.

Kitaplarda uygulamaya yönelik hazırlanan çalışma başlıklarının şu şekilde olduğu belirlenmiştir: "ta'lîmler", "temrîn", "kırâat", "vazifeler", "tenbîhler", "mülâhâzat", "meşk" ve "imlâ". Bu başlıklar nazari bilgilerin pekiştirilmesi, icra edilmesi, yazdırılması ve değerlendirilmesi amaçlarına göre belirlenmiştir. Ayrıca bu kitapta yirmi beş "çift sesli solfej" örneklerine de yer verilmiştir. Bu solfejlerin bir kısmı da sözlü eserlerdir. Kitapta geniş ölçüde yer verilen aksak ritimli usullerin öğretilmesinde Türk müziği eserlerine de yer verilmesi Türk müzik eğitimi, çift sesli solfej örnekleri ise çok sesli işitme eğitimi açısından önemli olduğu söylenebilir. Solfej yahud Nazariyat-ı Musiki ve Kütübhâne-i Musikiden Talim-i Kırâat-ı Musiki kitaplarının Türkçe Batı müziği terminolojisinin oluşmasında da önemli bir yer teşkil ettiği görülmüştür.

Anahtar kelimeler: Solfej, Talim-i kırâat-ı musiki, Mustafa Safvet Atabinen, Mehmed Zati Arca, Musika-i Hümâyun

\section{ABSTRACT}

During the Ottoman period in the time of Mahmud II (1826), the education of Western music started to be given formally alongside Turkish music by doing away 
with the janissary band, through the establishment of the military band, Muzıka-i Hümâyun and by the commissioning of the Italian composer Giuseppe Donizetti . Donizetti trained many students until his death in 1856. After that another Italian composer, Callisto Guatelli, was commissioned by Abdulhamid II until his death in 1899. The Spanish composer D'Arenda helped Guatelli in Muzıka-yı Hümâyun and replaced him later.Turkish students have published many books or translations of Western music theory and solfege education. One of the first and most important works among these publications is "Solfej Yahud Nazariyat-I Musiki (Solfege or Music Theory) (1888/1889)" by the flautist Mustafa Safvet [Atabinen] Bey, who is an educator of the Muzıka-i Hümâyun (The Imperial Band of the Ottoman Empire) and the other is "Kütübhane-i Musikiden Talim-i Kıraat-ı Musiki (Teaching and Reading of Music From Library of Music) (1899/1900)" by theviolinist Mehmed Zati [Arca] Bey, who is also an educator of the Muzıka-i Hümâyun. These works are the first printed Turkish solfege books of the Ottoman period. The aim of this study is firstly to examine the extant terms used by converting these two books from old letters to new letters and then to investigate the usability of the solfege samples included in the books in today's professional music education and to bring them into today's solfege education.

The titles of the works which were prepared for practice are determined as follows: "ta'lîmler", "temrîn", "kırâat", "vazifeler", "tenbîhler", "mülâhâzat", "meşk" and "imlâ".'These titles are determined according to the purposes of consolidating, performing, printing and evaluating the theoretical knowledge. Moreover, in this book, twenty five "two voice solfege" examples are also included. Some of these solfeges are vocal works. Turkish music works are used for teaching syncopated rhythms which occur frequently in the book. Moreover it can be said that two voice solfege examples are also crucial in terms of polyphonic hearing. It is seen that the books Solfej Yahud Nazariyat-ı Musiki and Kütübhâne-i Musikiden Talim-i Kırâat-ı Musiki play an important part in comprising the terminology of Turkish Western music.

Keywords: Solfege, Talim-i kıraat-ı musiki, Mustafa Safvet Atabinen, Mehmed Zati Arca, Musika-i Hümâyun

\section{EXTENDED ABSTRACT}

During the Ottoman period in the time of Mahmud II (1826), the education of Western music started to be given formally alongside Turkish music by doing away with the janissary band, through the establishment of the military band, Muzıka-i Hümâyun and by commissioning of the Italian composer Giuseppe Donizetti. Donizetti trained many students until his death in 1856, and later another Italian composer Callisto Guatelli was commissioned by Abdulhamid II until his death in 1899. The Spanish composer D'Arenda helped Guatelli in Muzıka-y1 Hümâyun and replaced him later.

It is well-known that, although Italian and Spanish composers had been educating many students and writing many works for piano and orchestra, they had not published any books on music education such as music theory, harmony, solfege or piano education. However the Turkish students they educated published many books or translations of the Western music theory and solfege education. One of the first and most important works among these publications is "Solfej Yahud Nazariyat-1 Musiki (Solfege or Music Theory) (1888/1889)" by the flautist Mustafa Safvet [Atabinen] Bey, who is an educator of the Muzıka-i Hümâyun (The Imperial Band of the Ottoman Empire) and the other is "Kütübhane-i Musikiden Talim-i Kıraat-1 Musiki (Teaching and Reading of Music From Library of Music) (1899/1900)" by the violinist Mehmed Zati [Arca] Bey, who is also an educator of the Muzıka-i Hümâyun. These works are the first printed Turkish solfege books of the Ottoman period. Although these works are important in terms of comprising the foundations of today's solfege education, it has been seen that some of these works have not been studied in detail even though they are 
mentioned in some studies. The aim of this study is firstly to examine the extant terms used by converting these two books from old letters to new letters and then to investigate the usability of the solfege samples included in the books in today's professional music education and to bring them into today's solfege education.

In this study, a qualitative research method is used. The qualitative research method is defined as the research, in which data collection methods such as observation, interview and document analysis are used and a qualitative process for realizing perceptions and events in a natural environment in a realistic and holistic manner (Yıldırım and Şimşek 2008: 39). The titles of the works which were prepared for practice in the books are determined as follows: "ta'lîmler", "temrîn”, "kırâat”, "vazifeler", "tenbîhler", "mülâhâzat”, "meşk” and "imlâ". These titles are determined according to the purposes of consolidating, performing, printing and evaluating the theoretical knowledge. The examples of each subject included in Kütübhâne-i Musikiden Nazariyat-ı Musiki are included in more detail in Kütübhâne-i Musikiden Talim-i Kırâat-ı Musiki. Moreover, in this book twenty five "two voice solfege" examples are also included. Some of these solfeges are vocal works. According to the note of Mehmet Zati Bey "no longer the practices will be made by solfege with piano in slow tempo from seventysecond and seventy-third item", up to the specified items they can be read without considering the pitches (bona), the next will be read briefly as solfege. The examples which are given in Kütübhâne-i Musikiden Talim-i Kırâat-ı Musiki can be listed as: gap-filling-completion, note reading (bona), note reading with piano (solfege), reading with different keys, reading vocal works, two voice solfege, finding modulation, transposition.

We can say that one of the most important features of Kütübhâne-i Musikiden Talim- $i$ Kırâat-ı Musiki is that it includes the oral works of various Turkish music composers. The yegâh song of Dellalzade (Piyale elde nidem bezmime habib gelir), the yegâh song of Latif Efendi (Va'di unutma ey peri), the hicaz song of Hacı Arif Bey (Kamer çehre peri-ru tende canım), the suzidil song of Dellalzade (gönül burcunda ol mahdır), the maye song of Kazasker Mustafa İzzet Efendi (Şeb midir bu ya sevad-ı ah-1 pinhânım mıdır), the Nevâ-Puselik song of Dellalzade (Ey menba-i ihsan-ü ata şah-1 melek zad) are placed with notes and lyrics. In these works, the aim is to teach rhythms of Turkish music. In this study, we conclude that Mustafa Safvet Atabinen prepared the work Solfej Yahud Nazariyat-ı Musiki by utilizing Theorie de la Musique by A. Danhauser dated 1872. It is seen that solfege, i.e. musical reading examples occupy a small place but it sets an example for preparation of the work Kütübhâne-i Musikiden Talim-i Kırâat-ı Musiki by Mehmet Zati Bey. Kütübhâne-i Musikiden Talim-i Kırâat-ı Musiki gives solfege and study examples. Turkish music works are used for teaching syncopated rhythms which occur frequently in the book (see Appendix 2). Moreover it can be said that two voice solfege examples are also crucial in terms of polyphonic hearing (see Appendix 3). It is seen that the books Solfej Yahud Nazariyat-ı Musiki and Kütübhâne-i Musikiden Talim-i Kırâat-ı Musiki play an important part in comprising the terminology of Turkish Western music. 


\section{Giriş}

Günümüzde solfej kısaca "müziksel okuma" olarak bilinmekte ve notaları, adları, ses yükseklikleri, süre, hız, gürlük ve detaylarıyla okumak olarak tanımlanmaktadır (Sun 2014: 1; Özgür ve Aydoğan 2015: 4). İtalyanca (solfeggio) ve Fransızca (solfege) terminolojiden Türkçe terminolojiye giren bu kavram, solfej eğitimi tarihi sürecinde farklı şekillerde tanımlandığı görülür. Yener'e göre solfej, şarkı egzersizlerinde yedi notanın sırayla okunması olarak tanımlanmaktadır. ${ }^{1}$ Fenmen'e göre solfej eğitimi, kulağımızın, gözümüzün ve reflekslerimizin eğitimiyle uğraşan ilk müzik tahsilidir ve solfej müziğin tamamen pratik kısmı ile yani reflekslerimizin inkişafı [gelişimi] ile meşgul olur. ${ }^{2}$ Öztuna (2002: 306) “do, re, mi gibi nota isimlerinin sesle teganni edilmesi şeklinde yapılan temrin" olarak tanımlamaktadır. Gazimihal ise solfeji üç şekilde tanımlamaktadır; ilk olarak; nota adları ile söyleyerek bir ses parçasını okumaktır. İkinci olarak, solfeje mahsus olarak yazılı parçalardan birleşik nota mecmuasına denilir. ${ }^{3}$ Son olarak da musikinin ihzarı [hazırlayıcı] bilgi ve prensiplerinin öğrenim ve öğretimine de solfej denilmektedir (Gazimihal 1961: 234).

Türkçe yazılı ya da basılı kaynaklar incelendiğinde Batı müziğine ilişkin “solfej” terimi ilk olarak Osmanlı döneminde on dokuzuncu yüzyılın son çeyreğinde karşılaşılsa da 1828 yılında Giuseppe Donizetti'nin Musika-i Hümâyun ${ }^{4}$ a göreve getirilmesi ile birlikte Batı müzik eğitiminin yanı sıra solfej eğitiminin başladığını söyleyebiliriz. Bilindiği gibi Donizetti Paşa, 1856'da vefatına kadar birçok öğrenci yetiştirmiş, ardından başka bir İtalyan besteci Callisto Guatelli 1899'da ölümüne kadar II. Abdülhamid tarafından görevlendirilmiştir. İspanyol besteci D'Arenda Musika-i Hümâyun'da Guatelli'ye yardım etmiş ve ondan sonra da yerine tayin edilmiştir.

İtalyan ya da İspanyol bestecilerin birçok öğrenci yetiştirmelerine, piyano ve orkestra için eserler yazmalarına karşın müzik teorisi, armoni, solfej ya da piyano eğitimi gibi müzik eğitimi üzerine herhangi bir kitap yayımlamamışlardır. Fakat yetiştirdikleri Türk öğrenciler, Batı müziği nazariyatı ve solfej eğitimine yönelik çeviri ya da telif birçok kitap yayınlamışlardır. Bu yayınlar arasında ilk ve en önemli eserlerden birisi Musika-i Hümâyun eğitimcilerinden flütist Mustafa Safvet [Atabinen] Bey'e ait Solfej Yahud Nazariyat-l Musiki (1888/1889) ve diğeri ise yine Musika-i Hümâyun eğitimcilerinden Mehmed Zati [Arca] Bey'e ait Kütübhâne-i Musikiden Talim-i Kırâat-ı Musiki (1899/1900) adlı eseridir. Bu eserler Osmanlı döneminin ilk basılı Türkçe "solfej” kitaplarıdır. Birbirinin devamı niteliğindeki bu eserlerin günümüz solfej eğitiminin temellerini oluşturduğu, bazı çalışmalarda adı geçse de üzerinde detaylı çalışma yapılmadığı görülmüştür.

Bu çalışmanın amacı ilk olarak Solfej Yahud Nazariyat-ı Musiki ve Kütübhâne-i Musikiden Talim-i Kırâat-ı Musiki kitabın eski harflerden yeni harflere çevirmek sureti ile kullanılan

Faruk Yener, Musiki Lugatı I-Garp Musikisi (İstanbul: Tasvir Neşriyatı Musiki Eserleri 1, 1944), 92.

Mithat Fenmen, Piyanistin Kitabı (Ankara: Doğuş Matbaası, 1947), 113.

M. Ragıp Gazimihal, Musıki Sözlüğü (İstanbul: Milli Eğitim Basımevi, 1961), 234.

Kitaplarda (موسيقئ همايون) yazılıdır. Bu çalışmada da yazım olarak “Musika-i Hümâyun” kullanılacaktır. 
terimlerin günümüze yansımalarını incelemek, daha sonra da kitaplarda yer verilen solfej örneklerinin günümüz mesleki müzik eğitiminde kullanılabilirliğini araştırmak ve günümüz solfej eğitimine kazandırmak olarak belirlenmiştir.

\section{Mustafa Safvet Bey ve Solfej Yahud Nazariyat-ı Musiki}

Mustafa Safvet Atabinen 1853 yılında İstanbul'da doğdu. 1863 yılında Musika-i Hümâyun'a girdi ve Guatelli Paşa ile çalıştı. Bir yıllığına Paris'e gönderildi ve Thedore Dubois'den armoni ve kompozisyon dersleri aldı. İstanbul'a döndü ve binbaşı rütbesi ile Musika-i Hümâyun'da göreve başlad1. 1908'de Musika-i Hümâyun'un başına geçti. 23 Haziran 1939'da vefat etmiştir. Başlıca eserleri şunlardır: Letafet (opera-komik), Ertuğrul (uvertür), zeybek (ballet), Chopin'in Impromtu'sunun piyano-flüt aranjmanı, Hicazkâr Müsemmen şarkı (Öztuna 2006: 122). Bu eserlerin dışında 1888 yılında Solfej yahud Nazariyat-ı Musiki adlı kitabını yayınlamıştır.

\subsection{Solfej Yahud Nazariyat-ı Musiki}

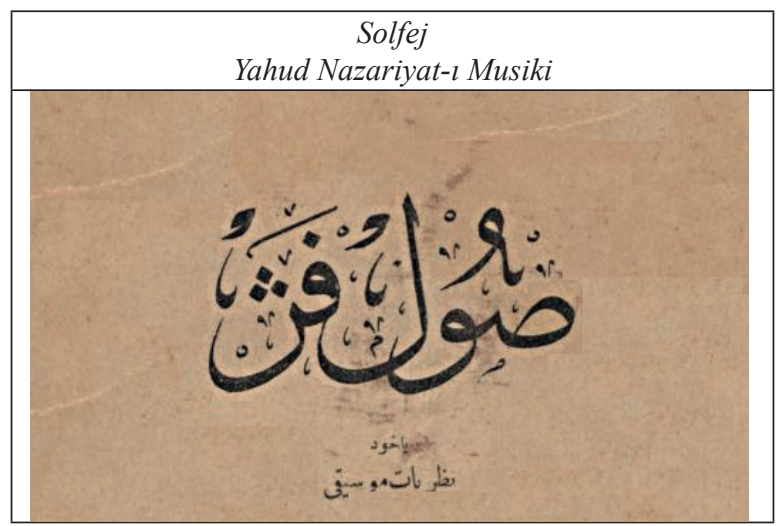

Resim 1. Solfej Yahud Nazariyat-l Musiki'de kapak sayfas1

1306/1888 tarihli bu eser 119 sayfadır. Maarif Nezaret Celîlesi’nin ruhsatı ile basılmıştır (ruhsat numarası yoktur). "Dibace” bölümünün sonunda "Musika-i Hümâyun kolağalarından M. Safvet” yazılıdır. Safvet Bey mukaddime bölümünde solfejin ne anlama geldiğini anlatmakta ve kitabın içeriği hakkında bilgiler vermektedir:

Solfej ciddi musiki eğitiminin aslı esası olup "Nazariyat" ve "Tatbikat" gibi başlıca iki kısma ayrılır. Nazariyat kısmı makam, usul konularından, musiki yazmak için kullanılan işaretlerden bahseder. Tatbikat ise yalnız notaların ismini telaffuz ederek terennüm etmeye denilmektedir. Bu risale her iki kısmın eğitimine de hidmet [hizmet] edebilirse de başlıca nazariyat kısmı iltizam olunmuştur [gerekli görülmüştür]. Her bölümün sonunda derslerle ilgili talimler bulunduğundan başka risalenin sonunda birkaç da sada talimi yani piyanoya tatbiken çağrılacak talimler yazılmış ve eklenmiştir (Safvet 1888: 5). 
Görüldüğü üzere, kitapta müzik teorisi eğitimine öncelik verildiği fakat derslerin sonlarında konu ile ilgili solfej talimlerine de yer verildiği anlaşılmaktadır.

Kitap beş kısımdan oluşmaktadır. Birinci kısım musiki yazmak için kullanılan işaretleri, ikinci kısım ölçüyü, üçüncü kısım dizi ve aralıkları, dördüncü kısım tonaliteyi, beşinci kısım işaretler ve nüanslar gibi musiki icrasında kullanılan bazı süslemeleri içermektedir (Safvet 1888: 5). Safvet Bey “Mebadi-i Esasiyye” başlıklı bölümde solfejin tanımını şu şekilde yapmaktadır; "Musiki işaret ve kaidelerinin tedris ve ta'lîmine solfej denir. Solfejin manası düm tek usulü ile terennüm etmek [şarkı gibi söylemek] bilimi demektir”.

Eserde yer verilen terminoloji incelendiğinde Fransızca terimlerin kullanıldığı rahatlıkla görülmektedir. Fransızca terimler hem Latin harfleri ile hem de Osmanlı Türkçesi ile yazılmıştır. Bu konu ile ilgili olarak Safvet Bey "Bu eserde 1stılâhât-1 musikiyi Fransız lisanında kullanıldığı şekliyle kabul etmiş olmama şayeste-i itiraz görülmez sanırım” sözleri ile Fransızca terminolojiyi olduğu gibi kabul ettiği anlaşılmaktadır (Safvet 1888: 4). Safvet Bey sebebini ise; o tarihe kadar zaten İtalyanca terimler kullanıldığını, İtalyanca ile Fransızca arasında büyük farklar olmadığını ve Fransızca terminolojinin musiki ilmî için daha faydalı olacağı, şeklinde açıklamaktadır. Kitapta kullanılan bazı terimler Tablo 1'de verilmiştir.

Bu eserde solfej örnekleri yok denecek kadar azdır. Kitap başlığı da dikkate alınırsa bu durum dikkat çekicidir. Fakat "ta'lîmler", "su'âller", "kırâat", "vazifeler", "tenbîhler", "mülâhâzat" [değerlendirme] ve "imlâ" başlıkları ile ele alınan bölümler mesleki müzik eğitimi kapsamında müzik teorisi eğitimi için önemli olduğu düşünülmektedir. Müzik teorisi bilgisi ta'lîmler, su'âller, vazifeler, tenbîhler ile desteklenmekte ve kırâat ve imlâ ile okutularak ve yazdırılarak uygulatılmaktadır. Kısaca bu başlıklardan hareketle diyebiliriz ki kitap, öğrencinin bilişsel ve devinişsel kazanımları için belli bir program dâhilinde hazırlanmıştır.

\section{Mehmed Zati Bey ve Kütübhâne-i Musikiden Talim-i Kırâat-ı Musiki}

Mehmed Zati Arca 1863 yılında İstanbul'da doğdu. Dokuz yaşında Musika-i Hümâyun'a girdi. Aranda ve Guatelli Paşa ile çalıştı. Ayrıca Hacı Arif Bey’den Türk musikisi öğrendi. 1890'da 60 kişilik bir koronun başına getirildi. 1900'de binbaşı, 1907'de miralay (albay) oldu. 1908 'de meşrutiyetin ilanından sonra rütbeler indirildi ve Mehmet Zati de binbaşılığa indirildi ve koro şefliği de Miralay Safvet Bey’e verildi. Daha sonraki yıllarında liselerde müzik öğretmenliği yaptı. Ayrıca Darülbedayi ve Darülelhan'da görevler aldı. 1951 yılında vefat etti. Hemen hemen hepsi çok sesli olan Türk makamları ve Batı müziğinde pek çok marş ve eserler yazdı (Öztuna 2006: 70). Bu eserlerinin dışında Kütübhâne-i Musikiden Nazariyat-ı Musiki ve bu eserine ek olarak yayınladığı Kütübhâne-i Musikiden Talim-i Kırâat-ı Musiki adlı kitaplarını yayınladı. Bu yayınları daha sonraki yıllarda birçok kere hatta yeni harflerle de basild1. 


\subsection{Kütübhâne-i Musikiden Talim-i Kırâat-ı Musiki}

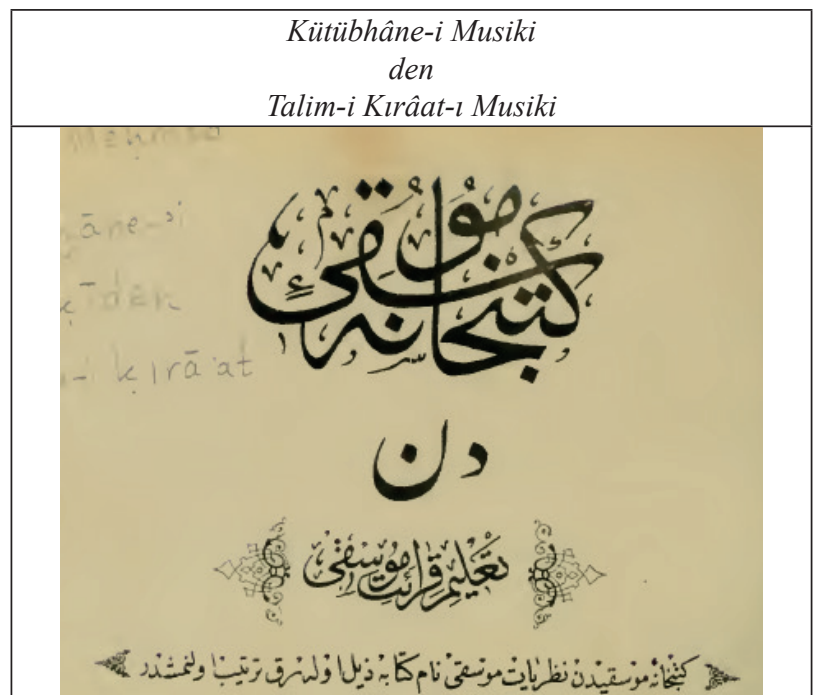

Resim 2. Kütübhâne-i Musikiden Talim-i Kırâat-ı Musiki adlı kitabın kapak sayfası

1316/1899 tarihli bu eser 64 sayfadır. Solfej Yahud Nazariyat-ı Musiki adlı eser gibi Maarif Nezaret Celîlesi'nin ruhsatı ile basılmıştır (ruhsat numarası 267). Kitabın kapak sayfasında da yazıldığı gibi eser yazarın bir önceki yayını olan Kütübhâne-i Musikiden Nazariyat-ı Musiki kitabına ek olarak hazırlanmıştır. Yine kitabın kapak sayfasından Mehmed Zati Bey'in Musika-i Hümâyun'a Muallim Sani ve Binbaşı olduğu bilgisine ulaşılmaktadır (Resim 2).

Mehmed Zati Bey “İfade-i Mahsusa” bölümünde kitabı yazma sebebine şu şekilde açıklamaktadır: "öğrencilerimin tedrisi esnasında adı geçen eserimdeki görülen kuralların kullanılmasına çalışmak için bir metot yazılmasına ihtiyaç duyulmuştur” (Zati 1899:2). “Talim-i Kırâat-1 Musiki” başlığından da anlaşılacağı üzere musiki kırâatı için yani “müziksel okuma" için hazırlanmış bir kitaptır diyebiliriz. Birinci kitap olan "Nazariyat-ı Musiki" de yer verilen bend numaralarına göre (yedinci bentten başlayarak) alıştırmalara yer verilmiştir. Bu alıştırmalar "vazifeler", "talimler”, "kırâat” ve "meşk” başlıkları adı altında verilmişstir. Talim-i Kırâat-1 Musiki’de müzik terimlerinden bahsetmek mümkün olmasa da Nazariyat-1 Musiki'de müzik terimleri ve anlamlarına ulaşmak mümkün olmaktadır. Nazariyat-1 musikinin konuları, içeriği ve yer verilen "ta'lîmler", "su'âller”, "kırâat”, “vazifeler”, "tenbîhler”, "mülâhâzat" [değerlendirme] ve "imlâ" başlıkları dikkate alındığında Mustafa Safvet Bey'e ait Solfej Yahud Nazariyat-1 Musiki kitabı ile neredeyse birebir benzerlikler vardır denilebilir. Gazimihal'e göre (1955: 126) Zati Bey kitabını Safvet Bey’in solfej eğitimini örnek alarak hazırlamış ve hatta Türk müziği bilgileri de kitabına katmıştır. Bu benzerliklerin Medmed Zati Bey'in Mustafa Safvet Bey ile olan mesai arkadaşlıkları ile de ilgilidir diyebiliriz. 
Bilindiği gibi Zati Bey'in yazdığı tiyatro eserlerine Safvet Bey müzikler yazmış, hatta Safvet Bey'in teori derslerine Zati Bey dinleyici olarak katılmıştır (Antep 2009: 32). Mehmed Zati Bey kitabında Safvet Bey'in kitabında yer verilen Fransızca terimlere karşı bir adım daha ilerleterek Türkçe terimler kullanmakta, Safvet Bey'in kitabındaki talimleri ve kırâat örneklerini genişletmektedir. Bu benzerlikten hareketle Solfej ve Talim-i Kırâat-ı Musiki kitapları birbirinin devamı şeklinde olduğu ve her iki kitabın birlikte değerlendirilmesi, incelenmesi gerektiği düşünülmektedir. Nazariyat-ı Musiki'de kullanılan bazı terimler karşılaştırmalı olarak Tablo 1'de verilmiştir.

\subsection{Kitaplarda Kullanılan Terminolojinin İncelenmesi}

Batı müziği ile ilgili terimlerin 1828'de Donizetti Paşa'nın Musika-i Hümâyun'da göreve getirilmesi ile kullanılmaya başladığı ve terimlerin doğal olarak İtalyanca olduğunu söyleyebiliriz. İlk basılı Türk musikisi edvar kitabı olan Haşim Bey Mecmuası'nda da kullanılan Batı müziği terimlerinden (1864) ve Ahmed Rıfat ve Kanuni Hasan Dede'ye ait Miftah-ı Nota adlı eserden hareketle 1874'e kadar İtalyanca terimlerin kullanıldığı ve 1875 tarihli Hüseyin Remzi’ye ait çeviri eser Usul-i Nota ile de Fransızca terimlerin etkili bir şekilde yerleşmeye başladığ 1 görülür. Hüseyin Remzi Usul-i Nota adlı kitabını Aleksandr Lagard'ın Fransızca Principes Elemantaire de Musique adlı kitabından çevirerek hazırlamıştır.

Fransizca kitaplardan çevirinin bir örneğinin de Mustafa Safvet Bey’e ait Solfej Yahud Nazariyat-ı Musiki adlı kitabının olduğu tespit edilmiştir. Safvet Bey, A. Danhauser'e ait 1872 tarihli Theorie de la Musique adlı eserinden neredeyse baştan sona, birebir çeviri yaptığ görülmüştür. Resim 3 'te konu anlatımı, örnekler ve talimler bakımından Solfej kitabının temel kaynağının Theorie de la Musique adlı eser olduğu görülmektedir.
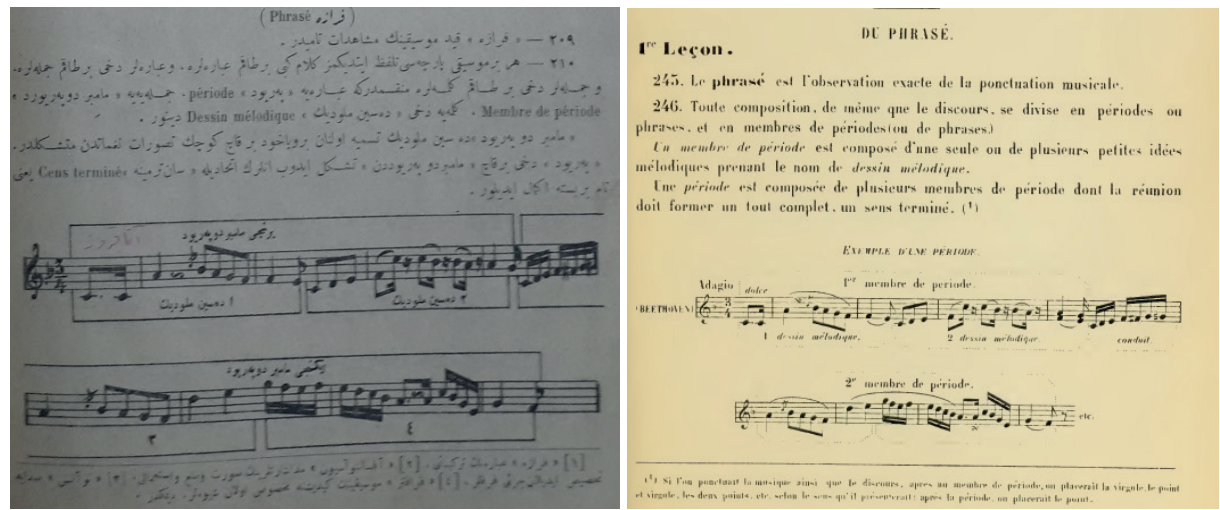

Resim 3. Solfej ve Theorie de la Musique adlı eserlerde "Phrase" konusu

Kütübhâne-i Musikiden Talim-i Kırâat-ı Musiki adlı eserin birinci cildi olan Kütübhâne-i Musikiden Nazariyat-ı Musiki adlı eserde de Solfej adlı eserden büyük ölçüde yararlanıldığı 
görülür. Hatta Zati Bey bazı bölümlerin alıntısını A. Danhauser'in eseri olan Theorie de la Musique ${ }^{5}$ 'den yaptığını belirtmektedir (Zati 1897:119). Fakat Fransızca terimlere karşı Mehmed Zati Türkçe terimler de geliştirmiştir. Bu önemli adımın yanı sıra Talim-i Kırâat (solfej) örnekleri ile de gerçek bir solfej eğitiminin geç kalınmış örneklerini Talim-i Kırâat- $\iota$ Musiki adlı eseri hazırlayarak ortaya koymuştur. Mehmed Zati Bey her iki eserinde de Fransızca terminolojiye karşı günümüze kadar ulaşacak birçok Türkçe terim geliştirmiş, kullanmış, hatta birinci kitabının son bölümünü bir nevi müzik sözlüğü olarak hazırlamıştır. Örneğin porte terimi yerine hutut, gam terimi yerine sıra, mezür yerine ölçü terimi önerilmiştir. Kitaplarda yer verilen terimlerin tamamı Ek 1'de verilmiştir. Bu terimlerden bazılarının hâlâ kullanılıyor olması bakımından mezkûr kitapların, günümüz musiki terimlerinin yerleşmesinde önemli bir etken olduğunu göstermektedir.

\section{Kitaplarda Uygulamaya Yönelik Kullanılan Çalışmaların İncelenmesi}

Kitaplarda uygulamaya yönelik hazırlanan çalışmaların başlıkları şu şekilde olduğu belirlenmiştir: "ta'lîmler", "temrîn”, "kırâat", "vazifeler”, "tenbîhler”, "mülâhâzat", "meşk” ve "imlâ". Bu başlıklar nazari bilgilerin pekiştirilmesi, icra edilmesi, yazdırılması ve değerlendirilmesi amaçlarına göre belirlenmiştir.

1. Tâ'limler: "öğretme”, “öğrenme”, "egzersiz” anlamlarına gelmektedir. Bu başlık adı altında kullanılan “...ezber olarak kırâat...”, “...notaların isimlerini üzerine yazma...”, “... misaller yazma...”, “...usul vurdurma...”, “...sual etme...” gibi cümleler incelendiğinde öğrenciye genellikle bilişsel ve devinişsel davranışlar kazandırmanın amaçlandığı söylenebilir.

2. Temrîn: "alıştırma”, "egzersiz” anlamına gelmektedir. Bu başlık adı atında öğrencilere "mürekkep usuller kaç nevidir, "hutut ne demektir", "koma ne demektir” gibi sorular sorulmakta, bilgi düzeyleri sinanmaktadır.

3. Kırâat: "okuma" anlamına gelmekte müzikte ise "müziksel okuma" anlamına gelmektedir. Kırâat başlı̆̆ı adı altında kullanılan “...Hoca Efendi... misaller yazıp talebeye kırâat ettirecektir”, “...her notayı piyanoya tatbiken kırâat ettirilmeli", "kırâatda sesin piyano ile tatbiki matlub değildir [istenilmemektedir]”, “...şakirdana piyanoya tatbiken birçok misaller okutturmalıdır...” gibi cümleler incelendiğinde solfej eğitimine yönelik davranışlar kazandırmanın amaçlandığı görülmektedir.

4. Vazifeler: "görev", “ödev” anlamına gelmektedir. Bu başlık adı altında verilen bölümlerde “...kle dö sol ile tatbik olunacak..." gibi cümleler kullanılmaktadır ki bir çeşit ödevler verilerek bilişsel davranış kazandırmanın amaçlandığı söylenebilir.

5. Tenbîhler: "uyarmak", "tembihlemek" anlamına gelmektedir. Bu başlık adı altında kullanılan “...fasılalar ile gayet iyi ülfet etmek [kaynaşmak, dostluk kurmak] lazımdır... piyanoya veyahut bir saza tatbiken fasılalara çalışmak lazımdır”, “...şakird yalnız ikinci hatta

5 Bu eser daha sonraki yıllarda da çeşitli müzik kuramcıları tarafından Türkçeye çevrilmiş ve yayınlanmıştır (Danhauser, Adolphe ve Baran, İlhan. Temel Müzik Kuralları. Ankara: Belgi Yayınları, 1988). 
vaz olunan kle dö sol ile nota okumaya çalışacaktır" gibi cümleler incelendiğinde konulara yönelik çeşitli uyarılarda bulunulduğu görülmektedir.

6. Mülahazat: "irdelemek”, "ayrıntılı düşünmek" anlamına gelmektedir. Sadece "solfej yahud nazariyat-ı musiki" kitabında görülen bu başlık adı altında konunun bazı ayrıntılarına dikkat çekilmektedir.

7. Meşk: "yazı örneği”, "temrin/alıştırma” anlamına gelmektedir. "Nazariyat-1 Musiki”"de yer verilen bu konu tâ'lim başıı̆g üzerine hazırlanmış örnekleri içermektedir.

8. İmlâ: "doldurma”, “yazı bilgisi”, “yazı” anlamına gelmektedir. Bu konu başlığı altında Mehmed Zati Bey “ “...Hoca Efendi... birçok misaller kırâat ettirmeli ve sonra mezkur kaidelere dair imlalar yazdırmalıdır", “. . diyezler ve bemoller üzerinden şakirdana imlalar yazdırarak...” şeklinde bilgiye dayalı çalışmalar yaptırırken Mustafa Safvet Bey ise “... hoca darbları göstererek kuvvetli bir sada ile atideki [aşağıdaki] talimin her mezürünü [ölçüsünü] birkaç kere yani şakirde tefhim edinceye kadar [anlatana kadar] terennüm edecek [okuyacak] ve şakird de işittiği ibareyi notaların valurlarına [değerlerine] tatbiken imla edecektir" şeklinde "müziksel dikte/yazma"ya dayalı olarak çalışmalar yaptırmaktadır.

\section{Kitaplarda Kullanılan Solfej Örneklerinin İncelenmesi}

Solfej Yahud Nazariyat-ı Musiki'de az da olsa solfej örneklerine yani müziksel okuma örneklerine yer verilmiştir. Bu örnekler "kırâat" başlı̆̆ı altında verilmekte ve kimi örnekler piyanoya uygun yani ses yüksekliği ile kimi örnekler ise piyanoya uygun olmadan yani nota isimleri ile (bona) okunması istenmektedir (Resim 4).

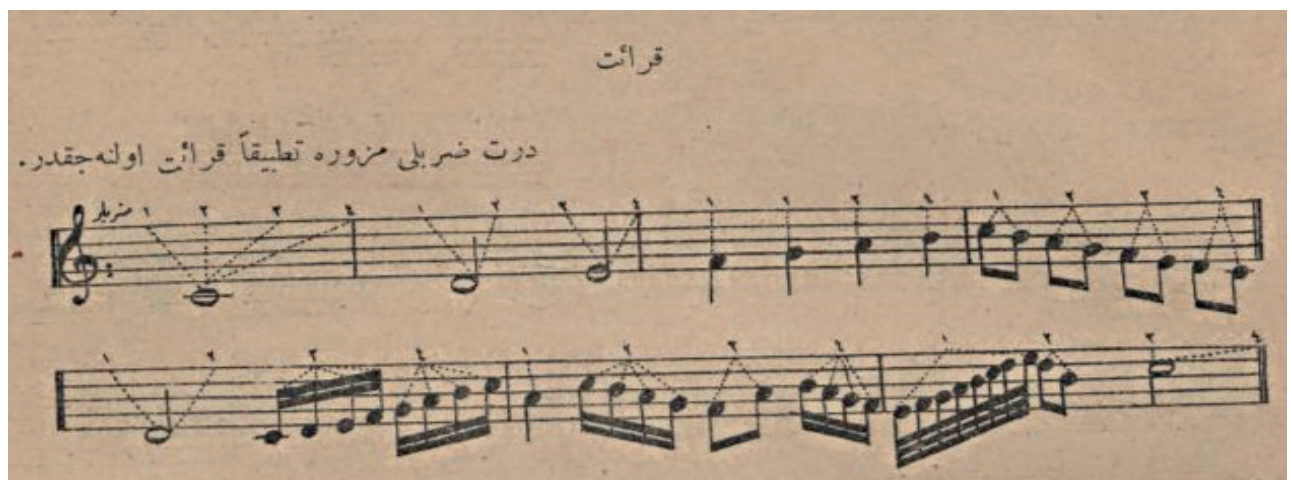

Resim 4. Solfej Yahud Nazariyat-ı Musiki'de kırâat örneği

Kütübhâne-i Musikiden Nazariyat-ı Musiki'de yer verilen her konunun örneklerine Kütübhâne-i Musikiden Talim-i Kırâat-ı Musiki'de genişletilmiş olarak yer verilmektedir. Ayrıca bu kitapta yirmi beş “çift sesli solfej” örneklerine de yer verilmiştir. Bu solfejlerin bir kısmı da sözlü eserlerdir. Mehmed Zati Bey'in şu notundan "bundan böyle atideki (yetmiş 
iki, yetmiş üçüncü maddeden itibaren) talimler gayet ağır olarak piyanoya tatbiken kırâat olunacaktır" anlaşıldığı üzere belirtilen maddelere kadar ses yükseklikleri dikkate alınmadan okunabilir (bona), sonrakiler ise kisaca solfej olarak okunacaktır.

Kütübhâne-i Musikiden Talim-i Kırâat-ı Musiki' de yer verilen örnekler şu şekilde sıralanabilir: boşluk doldurma-tamamlama, nota okuma (bona), piyanoya tatbiken nota okuma (solfej), farklı anahtarlarla okuma, sözlü eserler okuma, iki sesli okuma, modülasyon bulma, transpoze etme. Kütübhâne-i Musikiden Talim-i Kırâat-ı Musiki'nin en önemli özelliklerinden birisi de çeşitli Türk musikisi bestecilerinin sözlü eserlerine de yer verilmesidir diyebiliriz. Dellalzade'nin yegâh şarkısı (Piyale elde nidem bezmime habib gelir), Latif Efendi'nin yegâh şarkısı (Va'di unutma ey peri), Hacı Arif Bey'in hicaz şarkısı (Kamer çehre peri-ru tende canım), Dellalzade'nin suzidil şarkısı (gönül burcunda ol mahdır), Kazasker Mustafa İzzet Efendi’ye ait maye şarkı (Şeb midir bu ya sevad-ı ah-ı pinhânım mıdır), Dellalzade'nin Nevâ-Puselik şarkısı (Ey menba-i ihsan-ü ata şah-1 melek zad) notaları ve güfteleri ile verilmiştir. Bu eserlerde Türk musikisi usullerinin öğretilmesi amaçlanmaktadır. Solfej ve bona örneklerinin kolay ezgilerden zor ezgilere şeklinde sıralandığı ve aksak usullerin öğretilmesinde bilinen ezgilerden örnekler seçilmesi, eğitimin yakından uzağa, bilinenden bilinmeyene ya da çevreden evrene ilkesine uygun hareket edildiğini göstermesi bakımından önemlidir. Bu yönüyle kitapların günümüz mesleki müzik eğitiminde kullanılabilirliğine işaret etmektedir.

\section{Sonuç}

Bu çalışmada on dokuzuncu yüzyılın son çeyreğinde Türkçe basılmış Solfej yahud Nazariyat-ı Musiki ve Kütübhâne-i Musikiden Talim-i Kırâat-ı Musiki kitapları incelenmiştir. Bu kitaplar Osmanlı döneminde Musika-i Hümâyun eğitimcileri tarafından hazırlanmış ilk Türkçe basılı solfej kitaplarıdır. Mustafa Safvet Atabinen'e ait Solfej yahud Nazariyat-ı Musiki adlı eser A. Danhauser'e ait 1872 tarihli Theorie de la Musique adlı eserden yararlanılarak hazırlanmıştır. Solfej yani müziksel okuma örneklerinin az olduğu, fakat Mehmet Zati Bey’e ait Kütübhâne-i Musikiden Talim-i Kırâat-ı Musiki adlı eserin hazırlanmasında da örnek teşkil ettiği görülmüştür. Kütübhâne-i Musikiden Talim-i Kırâat-ı Musiki adlı eser solfej ve çalışma örnekleri üzerine hazırlanmıştır. Kitapta geniş ölçüde yer verilen aksak ritimli usullerin öğretilmesinde Türk müziği eserlerine de yer verilmesi Türk müzik eğitimi (bk. Ek 2), çift sesli solfej örnekleri (bk. Ek 3) ise çok sesli işitme eğitimi açısından önemli olduğu söylenebilir. Solfej yahud Nazariyat- $\iota$ Musiki ve Kütübhâne-i Musikiden Talim-i Kırâat-ı Musiki kitaplarının Türkçe Batı müziği terminolojisinin oluşmasında da önemli bir yer teşkil ettiği görülmüştür.

Solfej yahud Nazariyat-ı Musiki ve Kütübhâne-i Musikiden Talim-i Kırâat-ı Musiki adlı kitapların çevirilerinin yapılması ve yeni harflerle tekrar baskıları yapılarak Türkiye'de günümüz mesleki müzik eğitiminin önemli bir parçasını teşkil eden solfej eğitimine kazandırılması önerilmektedir. 


\section{Kaynaklar}

Antep, Esin. Osman Zeki Üngör ve Mûsikî İnkılâbı. Mimar Sinan Güzel Sanatlar Üniversitesi Sosyal Bilimler Enstitüsü, Yüksek Lisans Tezi, İstanbul, 2009.

Danhauser, Adolphe ve Baran, İlhan. Temel Müzik Kuralları. Ankara: Belgi Yayınları, 1988.

Develioğlu, Ferit. Osmanlıca-Türkçe Ansiklopedik Lugat. Ankara: Aydın Kitap Evi Yayınları, 2012.

Fenmen, Mithat. Piyanistin Kitabı. Ankara: Doğuş Matbaası, 1947.

Gazimihal, Mahmut Ragıp. Musıki Sözlüğ̈̈. İstanbul: Milli Eğitim Basımevi, 1961.

Gazimihal, Mahmut Ragıp. Türk Askeri Mızıkaları Tarihi, İstanbul: Maarif Basımevi, 1955.

Özgür, Ülkü ve Aydoğan, Salih. Müziksel İşitme Okuma Eğitimi ve Kuram. Ankara: Arkadaş Yayınevi, 2015.

Öztuna, Yılmaz. Türk Musikisi Akademik Klasik Türk San'at Musikisi’nin Ansiklopedik Sözlüğ̈̈ Cilt I-II, Ankara: Orient Yayınları, 2006.

Safvet, Mustafa. Solfej yahud Nazariyat-ı Musiki. İstanbul: Mahmud Bey Matbaası, 1888.

Sun, Muammer. Solfej 1. Ankara: Sun Yayınevi, 2014.

Yener, Faruk. Musiki Lugatı I-Garp Musikisi. İstanbul: Tasvir Neşriyatı Musiki Eserleri 1, 1944.

Zati, Mehmed. Kütübhâne-i Musikiden Talim-i Kırâat-ı Musiki. İstanbul: Mahmud Bey Matbaası, 1897. 


\section{EKLER}

Ek 1. Terimler

Tablo 1. Kitaplarda kullanılan bazı terimler

\begin{tabular}{|c|c|c|c|}
\hline \multicolumn{2}{|c|}{$\begin{array}{c}\text { Mustafa Safvet } \\
\text { Solfej Yahud Nazariyat-ı Musiki }\end{array}$} & \multicolumn{2}{|c|}{$\begin{array}{c}\text { Mehmed Zati- } \\
\text { Kütübhâne-i Musikiden Nazariyat-ı Musiki }\end{array}$} \\
\hline Yabancı Terim & Önerilen Terim & Yabanc1 Terim & Önerilen Terim \\
\hline Note & Not & Not & Not \\
\hline Ut & u - ut اوت - ut & Ut & - Ut - Do اوت \\
\hline $\operatorname{Re}$ & 0, re & $\mathrm{Re}$ & oj-re \\
\hline Mi & mi - مى - m - & $\mathrm{Mi}$ & mi - مى \\
\hline $\mathrm{Fa}$ & فا - fa & $\mathrm{Fa}$ & - a fa \\
\hline Sol & sol - صول & Sol & sol - صول \\
\hline $\mathrm{La}$ & $y-$ al & $\mathrm{La}$ & $\begin{array}{ll} \\
\end{array}$ \\
\hline $\mathrm{Si}$ & Si - si & $\mathrm{Si}$ & Si - si \\
\hline Portee & Porte & Porte & Hutut \\
\hline Gamme & Gam & Gam & Sira \\
\hline Solfege & Solfej & Solfej & Solfej \\
\hline- & Hat munzam & Hat munzam & Ek çizgi \\
\hline Octave & Oktav & Oktav & Sekizinci \\
\hline $\mathrm{Cle}$ & Kle-miftah & Kle & Anahtar \\
\hline Cle de fa & Kle dö fa & Kle dö fa & Fa anahtarı \\
\hline Cle de sol & Kle dö sol & Kle dö sol & Sol Anahtarı \\
\hline Cle de ut & Kle dö ut & Kle dö ut-kle dö do & Ut anahtar1-Do anahtarı \\
\hline Valeur & Valur & Valur & Kiymet \\
\hline Ronde & Rond & Rond & Birlik-Dört dörtlük \\
\hline Blanche & Blanş & Blanş & İkilik-iki dörtlük \\
\hline Noire & Nuar & Nuar & Dörtlük-bir dörtlük \\
\hline Croche & Kroş & Kroş & Sekizlik \\
\hline Double croche & Duble kroș & Duble kroş & On altılık \\
\hline Triple croche & Triple kroş & Triple kroş & Otuz ikilik \\
\hline Quatruplecroche & Katruple kroş & Katruple kroş & Altmış dörtlük \\
\hline Silence & Silans & Silans & Sükûn, Sükût, es \\
\hline Pause & $\mathrm{Poz}$ & Poz & Birlik es-Dört dörtlük es \\
\hline Demi-pause & Dömi-poz & Dömi poz & İkilik es-İki dörtlük es \\
\hline Soupir & Supir & Supir & Dörtlük es-Bir dörtlük es \\
\hline Demi-soupir & Dömi-supir & Dömi supir & Sekizlik es \\
\hline Quartdesoupir & Kart dö supir & Kart dö supir & On altılik es \\
\hline Huitiemedesoupir & Vitiyem dö supir & Vitiyer dö supir & Otuz ikilik es \\
\hline Seiziemedesoupir & Seziyem dö supir & Seziyem dö supir & Altmış dörtlük es \\
\hline Mesure & Mezür & Mezür & Ölçü-usul \\
\hline Temps & Tan & Tan & Zaman-darb \\
\hline Temps fort & Tan for/darb-1 sakil & Tanfor & Darb-1 sakil \\
\hline Temps faible & Tan febıl/darb-1 hafif & Tanfebil & Darb-1 hafif \\
\hline Chiffre & Şifre & Şifre & Rakam \\
\hline Puvan & Nokta & Puvan & Nokta \\
\hline Liaison & Liyezon & Liyezon & $\mathrm{Bağ}$ \\
\hline Mesur composee & Mezur kompoze & Mezur kompoze & Mürekkeb usul \\
\hline
\end{tabular}




\begin{tabular}{|c|c|c|c|}
\hline Mesure simple & Mezur simp11 & Mezur simpıl & Mezur simp11 \\
\hline Rhythme & Ritim-vezin & Ritim & Vezin \\
\hline Syncope & Sinkop & Sinkob (سينقوب) & Merbut \\
\hline Contre-temps & Kontru-tan & Kontrutan & Darb-1 ma'nus \\
\hline Point d'orgue & Puvan dorg & Puvandorg & Nokta-i imtidadiyye \\
\hline Point d'arret & Puvan darre & Puvandarre & Nokta-i tevakkuf \\
\hline Alteration & Alterasyon & Alterasyon & Tadilat \\
\hline Aksidan & Arrza & Aksidan & Arrza \\
\hline Diese & Diyez & Diyez & Diyez \\
\hline Bemol & Bemol & Bemol & Bemol \\
\hline Becarre & Bekar & Bekar & Naturel \\
\hline İntervalle & İnterval & İnterval & Fasıla \\
\hline İntervalle harmonique & İnterval armonik & İnterval armonik & Hem ahenk fasılalar \\
\hline Armature de cle & Armatür dö kle & Armür dö kle & Anahtarın cihazı \\
\hline Accentuation & Aksantü asiven & Aksantü asiven & Hareke \\
\hline Nuance & Nüans & Nüans & Fark \\
\hline Forte, piano & Forte, piyano & $F, p$ & Ef, $p$ \\
\hline Ornement & Orneman & Ornamen & Tezyinat \\
\hline Appogiature & Apajiyatür & Apajiyatür & Takid \\
\hline Mordant & Mordan & Mordan & Tehyic \\
\hline Enharmonie & Anarmoni & & \\
\hline Fioriture-cadenza & Fiyoritor-kadenza & Kadans & Kafiye \\
\hline Reprise & Repriz & Röpriz & Tekrar \\
\hline Akolad & Akolad & Akolad & Rabt \\
\hline Arpege & Arpej & Arpej & Sagirtme \\
\hline Mouvements & Muvman-hareket & Muvman & Hareket \\
\hline Gamme diatonique & Gam diyatonik & Gam diyatonik & Tabi el makam sıra \\
\hline Gamme chromatique & Gam kromatik & Gam kromatik & Mülevven \\
\hline Ton & طون - Ton & & \\
\hline Comma & Koma & Koma & Küçük fasıla \\
\hline İntervalle harmonique & İnterval Armonik & İnterval armonik & Fasıla-i ahenk \\
\hline İntervalle melodique & İnterval melodik & İnterval melodik & Fasıla-i nagamiyye \\
\hline Superieure & Superior & İnterval superior & Fevkani fasıla \\
\hline İnferieıure & İnferior & İnterval neferior & Tahtani fasıla \\
\hline Diminuee & Diminue & Diminue & Eksilmiş \\
\hline Augmentee & Ogmante & Ogmante & Artmış \\
\hline Majeure & Majör & Majör & Kebir \\
\hline Mineure & Minör & Minör & Sagir \\
\hline Juste & Jüst & Tam & Tam \\
\hline Renversement & Ranversman & Ranversman & Çevirme \\
\hline Ünison & ünison & Ünison & Hem sada-birinci fasıla \\
\hline Generateur & Jeneratör & Jeneratör & Müellid-esas olan \\
\hline Acord parfait majeure & Akor parfe & Akor parfe majör & $\begin{array}{l}\text { Mükemmel majör } \\
\text { mutabakatı }\end{array}$ \\
\hline Not diyatonik & Not diyatonik & Not diyatonik & Tabi el makam not \\
\hline Not tonale & Not tonal & Not tonal & Makama ait not \\
\hline Modes & Mod & Mod & Tarz \\
\hline
\end{tabular}




\begin{tabular}{|l|l||l|l|}
\hline Tonique & Tonik & Tonik & Makamı \\
\hline Dominante & Dominant & Dominant & Galib \\
\hline Sous-dominante & So dominant & Sudominant & Taht galib \\
\hline Note sensible & Not sansible & Sansible & Hassas \\
\hline Sus-tonique & Su tonik & Sutonik & Fevki makamı \\
\cline { 2 - 4 } Sus-dominante & Su dominante & Sumediyant & Taht vasati \\
\hline Mediante & medyant & Mediyant & Vasati \\
\hline Octave. Tonique & Oktav-Tonik & Oktav & Oktav-sekizinci \\
\hline & & Ton (ن) $)$ & Makam \\
\hline Tetracorde & Tetrakord & Tetrakord & Çehar sada \\
\hline Tetracorde İnferieiure & Tetrakord enferiyor & Tetrakord enferiyor & Fevkani çehar sada \\
\hline Tetracorde Superieure & Tetrakord süperiyor & Tetrakord süperiyor & Tahtani çehar sada \\
\hline Transposition & Transpozisyon & Transpozisyon & Takdim-i te'hir \\
\hline Armure & Armür & Donanım & Cihaz \\
\hline Modulation & Modülasyon & Modülasyon & Tebdil-i tarz \\
\hline
\end{tabular}


Ek 2. Kütübhâne-i Musikiden Talim-i Kırâat-ı Musiki`de Solfej Örneği

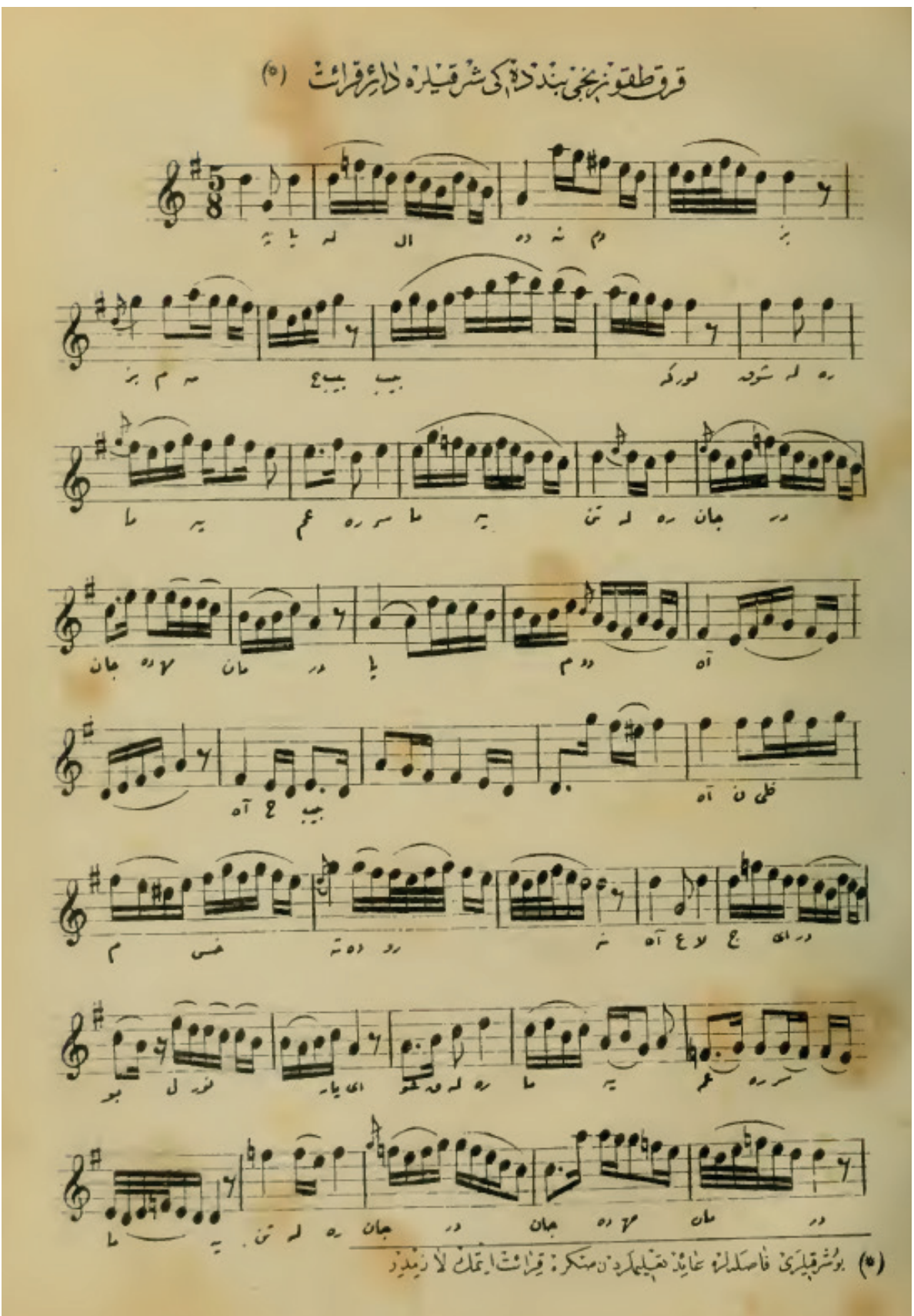


Ek 3. Kütübhâne-i Musikiden Talim-i Kırâat-ı Musiki'de Çift Sesli Solfej Örneği

iv
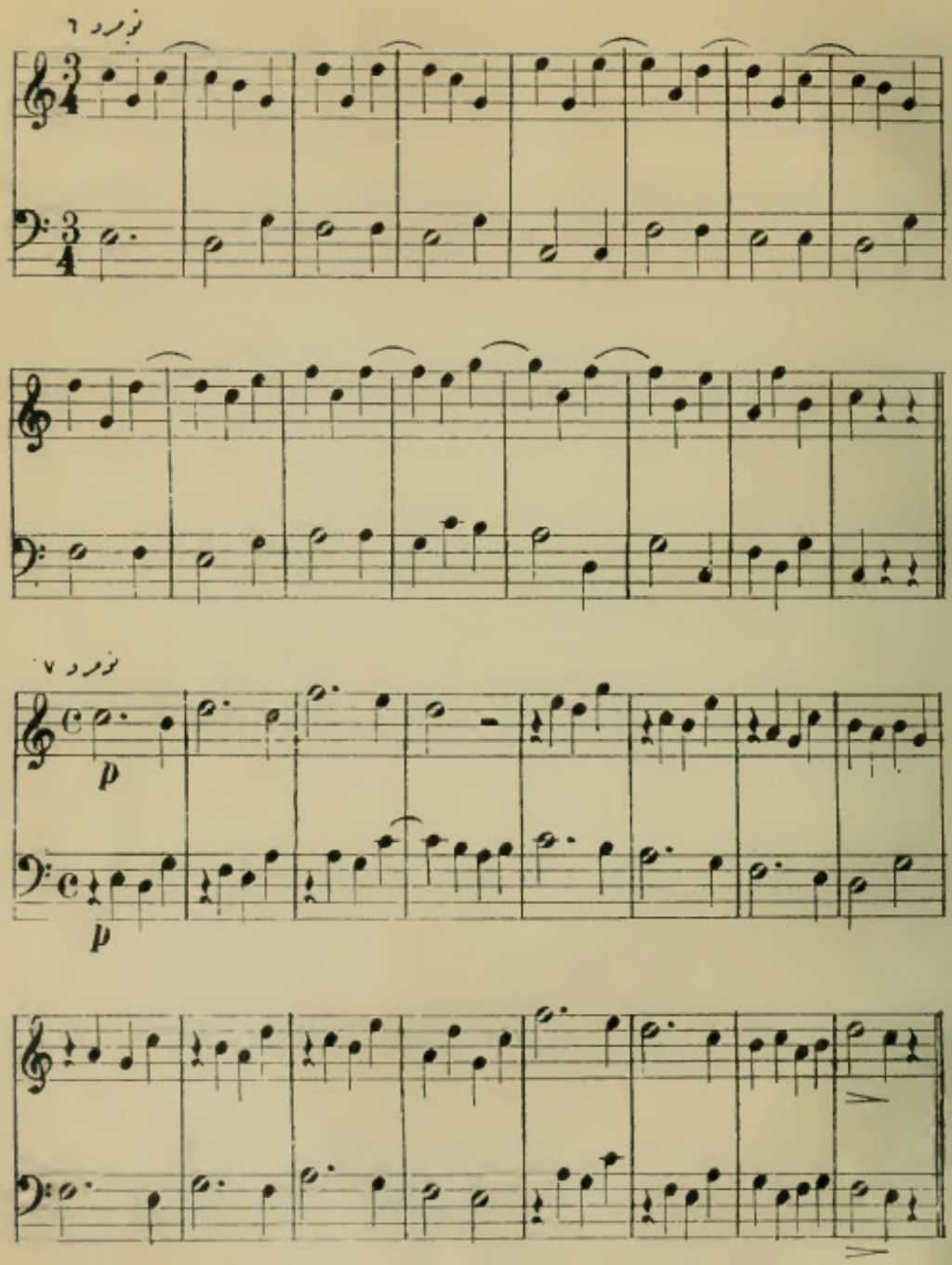
